\title{
Antioxidant Activity Saripati Beruwas Laut Fruit (Scaevola taccada)
}

\author{
Kiki Fatmawati $^{1}$, Azwin Apriandi ${ }^{1}$, Sri Novalina Amrizal ${ }^{1}$, Zubaidah Anjar Rezeki $^{1}$ \\ ${ }^{1}$ Fishery Products Technology Study Program, Faculty of Marine and Fisheries Sciences, \\ Raja Ali Haji Maritime University, Tanjungpinang 29111, Indonesia.
}

\begin{abstract}
Scaevola taccada is a coastal plant. This plant lives in gravel sandy soil and can prevent erosion that occurs on the beach. In the Riau Islands, it is still very rare, not even a few do not know the benefits of this plant, especially the fruit. The study aimed to determine the antioxidant activity of young, old, and mixed fruit extracts of S. taccada using the DPPH method which was stated to be IC50. The research methods include extraction, phytochemical test, antioxidant test and vitamin $\mathrm{C}$ test. The yield of pulp and water extract of young fruit was 55\% and $41.4 \%$, pulp and water extract of old fruit was $33.33 \%$ and $42.9 \%$, respectively. Phytochemical bioactive analysis was found to be positive for saponin parameters, indicated by the presence of stable foam for 30 minutes. Antioxidant activity using DPPH method obtained IC50 19,524 young fruit extract, IC50 50,664 old fruit extract, and IC50 35.518 mixed fruit. Analysis of Vitamin $\mathrm{C}$ in old S. taccada fruit yielded $5.28 \mathrm{mg}$, young fruit yielded $20.24 \mathrm{mg}$, and mixed fruit yielded $35.20 \mathrm{mg}$. The conclusion of this study is the presence of antioxidants and vitamin C in Scaevola taccada fruit.
\end{abstract}

Keywords: S. taccada, Antoxidant, Phytochemical, Vitamin C.

\section{Introduction}

Human life is not far from the presence of free radicals. Free radicals are any atom or group with one or more unpaired electrons [1]. Free radicals can cause various kinds of negative effects on body health, these negative effects can be in the form of pathophysiological diseases of the aging process and various degenerative diseases, namely cancer, diabetes mellitus and its complications, as well as atherosclerosis which underlies heart disease, blood vessels and stroke [2]. Free radicals can be formed continuously in the body, namely through normal cell metabolism events. Therefore, the body must scavenge free radicals from outside the body, one of which is antioxidants [3].

Antioxidants are compounds that can be used to overcome oxidative damage caused by free radicals [4]. Antioxidants are chemical compounds that can donate one or more electrons to free radicals, so that the work of free radicals can be inhibited [5]. Antioxidants can be classified into natural antioxidants and synthetic antioxidants. Natural antioxidants are in great demand, both used for food and medicinal ingredients as a substitute for synthetic antioxidants [6]. Natural antioxidants from outside the human body can be obtained from chemical compounds found in plants. One of the plants in question is the leaf of the Beruwas laut (Scaevola taccada), this plant has been used by the
Pinrang people of South Sulawesi and they call this plant as Sawi Laut.

Scaevola taccada is a coastal plant that is widely found in the Riau Islands. This plant lives in gravel sandy soil and can prevent erosion that occurs on the beach. People, especially the Riau Archipelago, are still very rare and even not a few do not know the benefits of this plant itself, especially on the fruit. The content of the Beruwas laut plant (Scaevola taccada) itself is in the form of alkaloids, phenolics, and saponins [7] The results of the phytochemical analysis of the compounds contained in the sample (S. taccada) were flavonoids, tannins and steroids. Study results [1] obtained the antioxidant value of Beruwas laut (Scaevola taccada) of 27.06 ppm. Research [7] antioxidant activity obtained IC50 values in chloroform leaf extract 0.1944 , methanol leaf 0.1034 , chloroform fruit 0.464 , and methanol fruit 0.653 . A good antioxidant value is below $200 \mathrm{ppm}$. The smaller the IC50 value, the better it is to ward off free radicals. Research conducted [8] shows that the vitamin content of the Beruwas laut fruit (Scaevola taccada) is vitamin A (12,415 SI), vitamin B12 (0.02 mg), vitamin E $(0.130 \mathrm{mg})$, vitamin C $(22,578 \mathrm{mg})$. Based on this description, it is necessary to research the antioxidant activity of the extract of the Beruwas laut fruit (Scaevola taccada). 


\section{Methods}

\subsection{Time and Place of Implementation}

The study was carried out from January to June 2021. Sampling was carried out at Tanjung Moco port, Dompak Tanjungpinang Island, Riau Islands followed by sample testing carried out at the Marine Chemistry Laboratory, Faculty of Marine and Fisheries Sciences, Raja Ali Haji Maritime University (UMRAH).

\subsection{Tools and Materials}

The tools used in this research are UV-VIS Spectrophotometer, blender, analytical balance, container, glass beaker, test tube, measuring flask, writing instrument, filter cloth.

The materials used in this study were the primary samples, namely old Beruwas laut (S. taccada), young Beruwas laut (S. taccada), aquadest, sulfuric acid, magnesium powder, alcohol, chloroform, acetic anhydride, $\mathrm{FeCl}$, hot water, $\mathrm{HCl} 2 \mathrm{~N}$, DPPH solution, methanol.

\subsection{Method"ggyk t78ir8i}

The main ingredients of this study were old fruit with white fruit characteristics, round with a diameter of 8$12 \mathrm{~mm}$, easy to press and for young fruit with green fruit characteristics, round with a diameter of 5-8 $\mathrm{mm}$. Samples in the form of Beruwas laut fruit were obtained in the coastal areas of Tanjungpinang and Bintan. Furthermore, this research was carried out in three stages, the first stage was sample preparation. The second stage of extraction is where the whole fruit is crushed using a crusher such as a blender without the use of solvents. The third stage is the phytochemical content test, the antioxidant activity test and the vitamin C content test from the extract of the Beruwas laut fruit (S. taccada).

\subsubsection{Sample Preparation}

Beruwas laut fruit (S. taccada) is the main sample in this study, the sample was obtained along the Dompak coast, Mocco Tanjungpinang port, Riau Islands. The samples were washed using running water to remove dirt and dust attached to the sea worms, then drained and continued with characterization observations.

1. Beruwas laut fruit morphology (Scaevola taccada); Morphological observations were carried out by measuring the shape, size, and the number of samples observed. The parts observed were young fruit and old fruit (fruit shape, size, fruit color).
2. Yield of Beruwas laut fruit (Scaevola taccada); Yield can be calculated based on the comparison of the final weight of the sample (the weight of the resulting extract) with the initial weight of the sample (the weight of the cell biomass used multiplied by $100 \%$ [9]. After sampling, it is done by determining the size and average weight. Beruwas laut (S. taccada) with as many as 30 fruits at random. The sample was calculated by the yield formula, namely:

\subsubsection{Extraction of Beruwas laut Fruit (Scaevola taccada)}

The extraction process was carried out using a crude extract process, in which a sample of $1 \mathrm{~kg}$ of Beruwas laut fruit (S. taccada) was taken in a fresh state, then the fruit was mashed using a blender. Then the sample is squeezed to produce the filtrate and residue. The obtained filtrate is in liquid form which is used as a crude extract and the yield calculation is carried out on the extract. The yield of Beruwas laut fruit Extract (S. taccada) [10]. Extraction yield is the ratio of the weight of the crude extract produced to the initial weight used

\subsubsection{Phytochemical Analysis of Beruwas laut Fruit (S. taccada)}

Phytochemical screening is a qualitative examination of chemical content to determine the class of compounds contained in a plant. The examination was carried out on secondary metabolites that have health benefits such as alkaloids, flavonoids, steroids, tannins, and saponins.

a. Alkoloid

The sample was dissolved in a few drops of $2 \mathrm{~N}$ sulfuric acid and then tested with Wagner's reagent. The results of the test if Wagner is positive will produce a brown precipitate [11].

b. Flavonoids

The sample was mixed with $0.1 \mathrm{mg}$ magnesium powder and $0.4 \mathrm{ml}$ amyl alcohol, then shaken. If the color becomes red, yellow or orange indicates a positive result.

c. Steroids

Some samples were melted in $2 \mathrm{ml}$ of chloroform in a non-wet test tube. Then 10 drops of acetic anhydride and 3 drops of concentrated sulfuric acid were added. Results with a red solution for the first time then turn blue and green indicate a positive result. 


\section{d. Saponins}

Solid saponins were detected by foam test in hot water. The foam was stable for 30 minutes and the addition of 1 drop of $2 \mathrm{~N} \mathrm{HCl}$ showed that the sample contained saponins. The characteristic properties of saponins include bitter taste, foaming in water and toxic to cold-blooded animals.

\subsubsection{Antioxidant Analysis}

The extract of Beruwas laut fruit (S. taccada) was dissolved in methanol at concentrations of 200, 400 and 600 ppm. DPPH fused is made by melting DPPH crystals into methanol solvent with a concentration of 1 $\mathrm{mM}$. Each test sample and comparison was taken 4.50 $\mathrm{ml}$ and reacted with 5001 of $1 \mathrm{mM}$ DPPH solution in a different test tube and was labeled. The solution was then incubated at $37^{\circ} \mathrm{C}$ for 30 minutes and the absorbance was measured using a UV-VIS spectrophotometer at a wavelength of $517 \mathrm{~nm}$. The absorbance of the blank was measured to calculate the percentage of inhibition. Blank solution was prepared by reacting $4.50 \mathrm{ml}$ of methanol solvent $50011 \mathrm{mM} \mathrm{DPPH}$ solution in a test tube. The percentage of inhibition values were plotted on the $\mathrm{x}$ and $\mathrm{y}$ axes, respectively, in the linear regression equation to find the IC50 value.

\subsubsection{Analysis of Vitamin C lodometric method (Rahim, 2016)}

A total of $20 \mathrm{ml}$ of the sample solution was put into a $50 \mathrm{ml}$ volumetric flask and filled with distilled water, then put into an Erlenmeyer. The sample was added with 3 drops of $1 \%$ starch solution and titrated with standard (I2) solution until it turned blue. The vitamin content can be calculated as follows:

\section{Results and Discussion}

\subsection{Characteristics of Beruwas Laut Fruit (Scaevola taccada)}

Beruwas laut (S. taccada) has glossy green-yellow leaves. The Beruwas laut fruit itself is white when old and green when young, imperfectly round in shape, while the Beruwas laut flower (S. taccada) is white decorated with orange color on the edges of the petals, and has 5 petals [7].
Beruwas laut fruit (Scaevola taccada) is round imperfectly slightly oval, the color looks like white sometimes has blackish-brown spots for old fruit and green color like the leaves for young fruit, this fruit has green petals that are difficult to fall off. In one branch there are young and old fruits with an average diameter of $\pm 8-11 \mathrm{~mm}$. The fruit water itself is green in color for young fruit and clear and cloudy for old fruit.

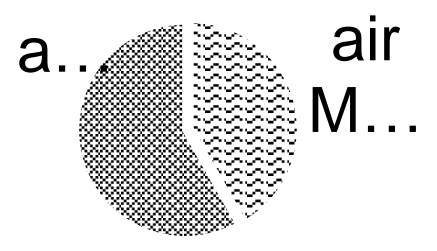

Figure 1. Yield of young and old Sceavola taccada fruit

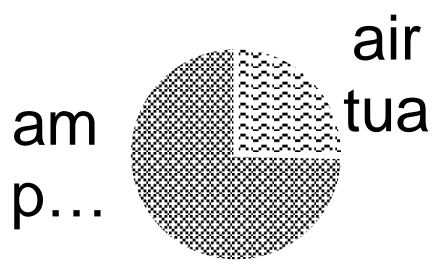

Figure 2. Yield of Water Extraction and Marine Fruit Pulp

\subsection{Yield Result}

Calculation of water yield and pulp of young and old fruit on 30 random samples. The yield results showed that young fruit juices were $42 \%$, young fruit pulp was $58 \%$, old fruit juices were $25 \% .75 \%$ old fruit pulp. The percentage of water and dregs yield can be seen in Figure 1.

\subsection{Results of Extraction of Beruwas laut Fruit (Scaevola taccada)}

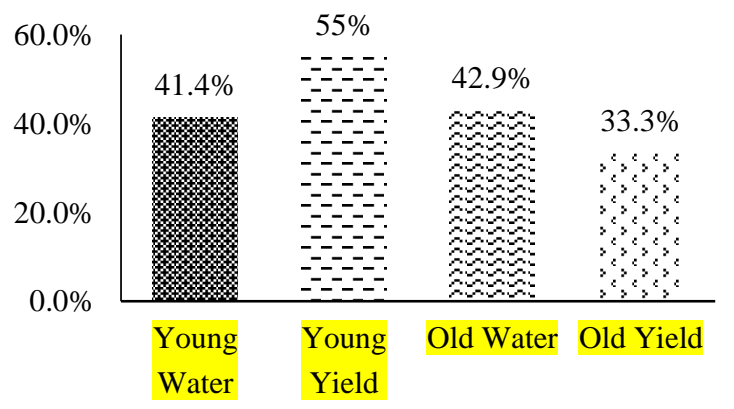


results of the phytochemical screening of S. platensis showed a positive presence of saponins only in polar solvents [13].

Ecrude extract of old S. taccada fruit produced brown pulp and crude extract of young $S$. taccada fruit produced brownish-green pulp. Furthermore, the old fruit water of S. taccada is cloudy brown, and the young fruit water of S. taccada is dark green. Calculation of water extraction yield and overall young and old fruit pulp. Extraction yield is a comparison of the weight of the crude extract produced with the initial weight used [12]. The yield results showed that young fruit juice was $41.4 \%$, young fruit pulp was $55 \%$, old water was $42.9 \%$, old fruit pulp was $33.3 \%$. The percentage of water extraction and dregs yield can be seen in Figure 2.

\subsection{The Phytochemical Content of Beruwas laut Fruit (Scaevola taccada)}

Table 1. Phytochemical test results of marine Beruwas laut fruit (Scaevola taccada) and their comparison.

\begin{tabular}{|c|c|c|c|c|c|}
\hline \multirow{2}{*}{} & \multicolumn{5}{|c|}{ Sample } \\
\cline { 2 - 6 } & $\begin{array}{c}\text { Young } \\
\text { Fruit }\end{array}$ & $\begin{array}{c}\text { Old } \\
\text { Fruit }\end{array}$ & $\begin{array}{c}\text { Mixed } \\
\text { Fruit } \\
\text { Extrac } \\
\mathrm{t}^{*}\end{array}$ & $\begin{array}{c}\text { B. } \\
\text { Methan } \\
\text { ol } \\
\text { (Rudian } \\
\text { to } \text { et al. } \\
2019)^{*}\end{array}$ & $\begin{array}{c}\text { B. } \\
\text { Chlorophoro } \\
\text { me } \\
\text { (Rudianto } \text { et } \\
\text { al., 2019)* }\end{array}$ \\
\hline $\begin{array}{c}\text { Alkoloid } \\
\text { ct * }\end{array}$ & - & - & - & - & - \\
\hline $\begin{array}{c}\text { Flavonoi } \\
\text { ds }\end{array}$ & - & - & - & - & + \\
\hline Steroids & - & - & - & + & + \\
\hline Saponins & + & + & + & - & - \\
\hline
\end{tabular}

Phytochemical test results in Table 1 show that the bioactive components in S. taccada fruit indicate the presence of saponins. The saponin analysis on the three samples was positive for saponins because the foam was stable for 30 minutes and the foam did not disappear with the addition of 1 drop of $2 \mathrm{~N} \mathrm{HCl}$. Saponin compounds are polar and are indeed found in many plants. Saponins are a glycoside form of sapogenins so they are polar. Saponins are polar so they can dissolve in solvents such as water and saponins are also non-polar because they have a hydrophobic group, namely an aglycone (sapogenin). in their research stated that the

\subsection{Analysis Vitamin C}

In this study, vitamin $\mathrm{C}$ was analyzed using the iodimetric method (direct titration). If all samples of vitamin $\mathrm{C}$ have been added with iodine, the next drop of iodine during the titration process reacts with the starch indicator solution to form blue iodate. The presence of a blue color indicates that the titration process has ended because all vitamin $\mathrm{C}$ has been added with iodine so that the volume of iodine required during the titration is equivalent to the amount of vitamin $\mathrm{C}$

Table 2. Levels of Vitamin C Extracts of the Beruwas Laut (Scaevola taccada) fruit extract.

\begin{tabular}{|l|c|}
\hline \multicolumn{1}{|c|}{ Sample } & Yield (Mg) \\
\hline Old Fruit & 5.28 \\
\hline Young Fruit & 20.24 \\
\hline Mixed Fruit & 35,20 \\
\hline Beruwas laut Fruit* & 22.578 \\
\hline Wet Candied Karisa Dieng** & 65.12 \\
\hline (Pamungkas et al., 2019) & \\
** (Rahayu \& Personal, 2012)
\end{tabular}

Based on Table 2. The vitamin C content of the old Beruwas laut got a yield of $5.28 \mathrm{mg}$, young fruit with a yield of $20.24 \mathrm{mg}$, and mixed fruit with a yield of 35.20 $\mathrm{mg}$. Raw fruits contain higher levels of vitamin $\mathrm{C}$ than ripe fruits. Vitamin $\mathrm{C}$ levels in fruit will increase until the fruit is ripe, and will decrease when the level of maturity has been exceeded. This is because the levels of vitamin C in overripe fruit will turn into glucose [14]. The vitamin $\mathrm{C}$ content of the Beruwas laut fruit (Scaevola taccada) from the study [15] obtained a result of 22,578 mg. Research [16] Vitamin content in candied Karisa Dieng is $65.12 \mathrm{mg}$. Based on the results of the study [15] it is known that the value of vitamin C content in Beruwas laut fruit (Scaevola taccada) is higher than the vitamin $\mathrm{C}$ content in wet candied Karisa Dieng. The riper the fruit or yield, the more water content, total dissolved solids, color, aroma, fruit texture, starch and sugar content increase while the vitamin $\mathrm{C}$ content generally decreases [17].

\subsection{Antioxidant Activity}


Analysis of antioxidant activity in the research of marine Beruwas laut fruit extract using the DPPH method. The use of this method considers that this method is a simple, easy method and uses a short time and requires a small sample [18].

Table 3. Comparison of antioxidant analysis of Beruwas laut fruit (Scaevola taccada)

\begin{tabular}{|c|c|c|c|c|}
\hline \multirow{2}{*}{$\begin{array}{c}\text { Sample } \\
\text { S. tacaada }\end{array}$} & \multicolumn{3}{|c|}{ \% Inhibit } & \multirow{2}{*}{ IC $_{50}$} \\
\cline { 2 - 4 } & 200 & 400 & 600 & \\
\hline Young Fruit & 68.45 & 77.16 & 84.62 & $19.516 \mathrm{ppm}$ \\
\hline Old Fruit & 79.93 & 82.57 & 83.29 & $48,714 \mathrm{ppm}$ \\
\hline Mixed Fruit & 56.97 & 70.61 & 74.04 & $23,354 \mathrm{ppm}$ \\
\hline $\begin{array}{c}\text { Marine- } \\
\text { based BM* }\end{array}$ & 57.48 & 64.92 & 80.44 & $0.47 \mathrm{ppm}$ \\
\hline $\begin{array}{c}\text { Marine- } \\
\text { oriented BK* }\end{array}$ & 57.94 & 64.65 & 81.36 & $0.46 \mathrm{ppm}$ \\
\hline Vitamin C & - & - & - & $2.72 \mathrm{ppm}$ \\
\hline
\end{tabular}

Note: * (Rudianto et al., 2019).

A good antioxidant is an antioxidant that has an IC50 value of less than $200 \mathrm{ppm}$. The smaller the IC50 value, the better it is to ward off free radicals [8]. The results of antioxidant analysis using the DPPH method obtained IC50 results of 19,516 for young fruit extracts, and IC50 results of 48,714 for old fruit extracts, and IC50 results of 23,354 for young and old (mixed) fruits. For the results of previous studies conducted [7] the IC50 results for methanol were 0.47 , and the IC50 results for chloroform fruits were 0.46 . This means that IC50 with ordinary extracts still gets a less good value compared to previous studies using solvents for extraction. This can be seen in table 2, while as a positive control vitamin C has an IC50 value of 2.72 and as a comparison, the methanol extract of tamarind fruit has an IC50 value of 26.828 and the methanol fraction extract has an IC50 value of 12.333. A good antioxidant is an antioxidant that has an IC50 value of less than 200 ppm.

\section{Conclusion}

Based on the research conducted, we can conclude that there are activities antioxidant using the DPPH method which obtained an IC50 value of 19.524 Extract of young fruit, IC50 50,664 essence of old fruit, and IC50 of 35,518 fruit mixed, the best activity was obtained by the treatment of young fruit extract. Analysis of Vitamin C in old S. taccada fruit obtained
$5.28 \mathrm{mg}$, young fruit yields $20.24 \mathrm{mg}$, and mixed fruit yields $35.20 \mathrm{mg}$.

\section{References}

1. A. A. Dahlia, R. Kosman, and H. Halija, Jurnal Ilmiah As-Syifaa 05, 62 (2013).

2. J. Managerxot and A. Werdhasari, Jurnal Biotek Medisiana Indonesia 3, 59 (2014).

3. D. Serlahwaty, S. Sugiastuti, and R. C. Ningrum, Jurnal Ilmu Kefarmasian Indonesia 9, 143 (2011).

4. D. Wulansari and C. Chairul, Majalah Obat Tradisional 16, 22 (2015).

5. E. al Ridho, Jurnal Mahasiswa Farmasi Fakultas Kedokteran UNTAN 1, (2014).

6. R. A. Priyanto, Aktivitas Antioksidan Dan Komponen Bioaktif Pada Buah Bakau (Rhizophora Mucronata Lamk.), 2012.

7. R. Rudianto, R. M. S. Putri, and A. Apriandi, Marinade 2, 29 (2019).

8. M. Sari, A. Apriandi, and M. Suhandana, Marinade 3, 37 (2020).

9. R. N. Sani, F. C. Nisa, R. D. Andriani, and J. M. Maligan, Jurnal Pangan Dan Agroindustri 2, 121 (2013).

10. N. P. P. Aristyanti, N. M. Wartini, and I. B. Wayan, Jurnal Rekayasa Dan Manajemen Agroindustri 5, 13 (2017).

11. H. Hafiluddin, N. Nurjanah, and T. Nurhayati, Jurnal Ilmiah Perikanan Dan Kelautan 3, 1 (2011).

12. S. Sudirman, Aktivitas Antioksidan Dan Komponen Bioaktif Kangkung Air (Ipomoea Aquatica Forsk), IPB (Bogor Agricultural University), 2011.

13. E. A. Shalaby and S. M. M. Shanab, IJMS 42, 1 (2013).

14. Y. Oktoviana, S. Aminah, and J. Sakung, Jurnal Akad Kim 1, 193 (2012).

15. A. N. Pamungkas, A. Apriandi, and M. Suhandana, Marinade 2, 30 (2019).

16. E. S. Rahayu and P. Pribadi, Biosaintifika: Journal of Biology \& Biology Education 4, (2012).

17. E. Julianti, Jurnal Hortikultura Indonesia 2, 14 (2011).

18. M. Masrifah, N. Rahman, and P. H. Abram, Jurnal Akademika Kimia 6, 98 (2017). 